Article

\title{
Everyday Radicalism and the Democratic Imagination: Dissensus, Rebellion and Utopia
}

\author{
Dan Silver \\ Department of Politics, University of Manchester, Manchester, M13 9PL, UK; E-Mail: daniel.silver@manchester.ac.uk
}

Submitted: 2 October 2017 | Accepted: 13 December 2017 | Published: 3 April 2018

\begin{abstract}
The prevalence of social injustice suggests the need for radical transformation of political economy and governance. This article develops the concept of 'everyday radicalism', which positions the everyday as a potential site of social change. Everyday radicalism is based on three main elements: dissensus and a rupture with dominant practices; collective rebellion and the creation of alternatives on a micro-scale; and the connection of these practices with utopian ideas to be able to develop strategies for social justice. The potential application of everyday radicalism is illustrated through a case study of a women's social intervention in Manchester. The article aims to show how everyday radicalism has the potential to contribute knowledge towards the transformation of everyday life and the institutions that govern society.
\end{abstract}

\section{Keywords}

democracy; governance; political economy; prefigurative; radical; utopia

\section{Issue}

This article is part of the issue "Co-Producing Urban Governance for Social Innovation", edited by Liz Richardson (University of Manchester, UK).

(C) 2018 by the author; licensee Cogitatio (Lisbon, Portugal). This article is licensed under a Creative Commons Attribution 4.0 International License (CC BY).

\section{Introduction}

The need for radical social and political transformation feels as distant as it does urgent. We are living in times of austerity, increasing inequality, a retrenchment of democracy, the rise of far-right nationalism, and ecological catastrophe. Streeck (2016) argues that the coming collapse of financial capitalism will result in a multitude of disorders and instabilities. Morin (1999) has identified this as 'polycrisis', in which all these crises are inextricably connected and in turn contribute to each other. Morin emphasises that a fundamental and multilevel re-definition of political economy and governance is needed. Such a profound change requires the radical transformation of everyday life and the institutions that govern society. Walby $(2015$, p. 7) maintains that the conflict between democracy and capitalism can only be resolved through a deepening of democracy. This resolution must include a democratisation of everyday life, in which competition is replaced with cooperative relationships (Bookchin, Bookchin, \& Taylor, 2015).
Marginality that is produced as a result of policy is experienced by people in their everyday lives. For instance, the intensification of punitive social policies following the financial crisis of 2007-2008 (Blyth, 2013; Bruff, 2014), have been experienced through daily struggles of hunger, poor health, unemployment and insecurity. There is a gendered and racialised political dimension to this injustice, which increases existing inequalities (Bassel \& Emejulu, 2017). As well as a site of injustice, the everyday can also be a source of resistance and a resource for critical social science. This article argues that knowledge of everyday resistance can inform a broadening of the democratic imagination, expanding the possibilities for more socially just forms of democracy.

The local level is closest to the 'arenas of everyday life in which people are able to resist power and construct their own voice' (Gaventa, 2006, p. 28). The 'starting point for participation and democracy', according to Sitrin and Azzellini (2014, p. 67), 'is the local'. It is at the municipal level where institutional politics are most closely connected to people's daily lives. Municipal gov- 
ernance is deeply embedded in the politics of everyday life, in terms of neighbourhood, education, culture, services and jobs. Yet even at a municipal level where there are more possibilities for radical forms of governance, everyday experiences are often neglected from the policymaking process.

The marginalisation of everyday knowledge from governance contributes to what Jacques Rancière has termed 'passive equality', in which publics outside of the structures of decision-making are assigned roles as passive objects (May, 2011). The marginalisation of everyday knowledges from governance has implications for the power relations in society and the types of actors who hold the position to shape the framings and practices of democracy. The elite and technocratic framing of the future means that democratic innovations are limited within the system. This limitation happens because the actors who have the power to shape policy are part of the status quo. The neglect of everyday knowledge isolates policy-making from experiences of marginality and means that policy is restricted within the frameworks that maintain the existing political economy of capitalism.

Radical democracy provides a more expansive ambition for politics than the technocratic management of the dominant political economy that characterises contemporary forms of governance. Little and Lloyd (2009, p. 1) identify three common features of radical democracy: first, that democracy is understood as an openended and contestable process; second, that civil society, rather than the state, is the main site of democratic struggle; and finally, that democracy should be seen not simply as a form of government or set of institutions, but rather the practice of politics by different publics.

Civil society is identified through radical democracy as the foundation for a renewed public sphere, which can serve as the basis to radically transform social relations and open up institutions to political contestation. This contestation means that democracy is said to exist in an open state which necessitates 'disruption and renewal' (Little \& Lloyd, 2009, p. 3). Bang (2005, p. 180) argues for more constructive engagement with 'ordinary politics', which are expressed by civil society at a local level. New ideas and approaches to address social problems can be developed through placing greater value on the ideas, assets and capacities of publics (Durose \& Richardson, 2015, p. 43). Through engagement with these ideas, it is possible to test and expand the 'democratic imagination'.

The potential for learning from civil society currently remains unfulfilled. There is an absence of meaningful connection between 'ordinary politics' and formal governance as the innovations that take place outside of institutions are often neglected by policy-makers. This disconnection happens even when measures to increase participation have been followed. Bang (2005) identifies the rise of 'expert citizens' who have become an established part of governance arrangements as part of a shift to make governance more participatory. The demo- cratic benefits of this involvement have often not been realised as expert citizens have become increasingly disconnected from the communities that they are put forward to represent. Bang contrasts expert citizens with the idea of 'everyday makers'. Everyday makers are defined as people who get involved in local, concrete and Do-It-Yourself (DIY) projects that make an immediate difference to people's lives and can positively impact the local community in a tangible way. These practices can be described as DIY social action (Richardson, 2008). Bang $(2005$, p. 180$)$ argues that the rise of expert citizens and the relatively marginalised position of everyday makers in governance means that opportunities for learning from everyday politics are missed.

There is scope to improve the capacity of public policy to address social problems through connecting with the practices of everyday makers. The knowledges and new ideas that are produced through the practices of everyday makers can be used to expand the boundaries of public policy. Social science can contribute to the broadening of the democratic imagination through relating theories of radical democracy and scholarship on everyday life to the practices of everyday makers.

Gardiner (2010, p. 231) identifies two largely divergent approaches to the study of everyday life. One approach is about understanding the textures of lived experience, while he characterises the other approach as being an:

overtly political project that aims to interrogate daily life in a critical fashion, to identify the various alienations and subjectification felt to be located at the heart of our experience of capitalist modernity, as well as to realise as fully as possible the emancipatory potential that is felt to inhere in the everyday.

Gardiner identifies the radical potential of the everyday through this second approach, but leaves a problematic in terms of how the everyday can be politicised to contribute knowledge for radical democracy. This article will argue that relating theories of radical democracy to the practices of everyday makers can contribute knowledge for democratic innovation. At the same time, this interaction can ensure that theories of radical democracy remain resonant with contemporary struggles for social justice. A concept of everyday radicalism will be articulated that can serve as a basis for developing theoreticallyinformed knowledge of practice to inform the transformation of everyday life and the institutions that govern society. Everyday radicalism will be illustrated through a case study of a women's project in Manchester, England.

\section{Assembling a Conceptual Framework for Everyday Radicalism}

Wright $(2010$, p. 108) argues that social theory alone cannot be used effectively or democratically as a basis to construct alternative futures, as the process of social 
change is too complex and contingent on local circumstances. A more open-ended approach to developing radical democracy is required that connects theory and practice. This approach must be adaptable, emergent and resonant with contemporary injustices. Relating theories of radical democracy to the practices of everyday makers can contribute towards a social science that is normatively based, empirically focused and which is guided by a practical purpose of overcoming injustice. The following section draws together theories of radical democracy to inform everyday radicalism. The concept of everyday radicalism is based on the ways in which social action creates a rupture with the everyday; how collective rebellion can articulate an alternative way of 'doing'; and how the combination of critique and alternative practice can form the foundation for prefigurative thinking about transformative social relations.

An understanding of the ways in which DIY social action firstly breaks with the status quo is necessary to develop a foundation for expanding the democratic imagination. The first element of everyday radicalism considers the ways in which there is a rupture from the dominant mode of political economy. The idea of 'dissensus' articulated by Rancière is particularly illuminating in opening up possibilities for understanding this basis of everyday radicalism. Rancière emphasises that 'politics begins and ends in a dissensus' (May, 2011). Dissensus is the moment when the dominant discourse becomes disrupted. This disruption provides an immanent critique of social relations. Through practices that reject the consensus of the status quo, dominant discourses are unsettled, and everyday social relations are questioned. This disturbance in the sediment of the status quo is necessary if alternative practices are to be constructed. To understand how such practices can provide the basis for transformation to established social relations, it is critical to figure out what constitutes the original point of rejection and provides the basis of departure.

For Rancière, dissensus does not happen in particular places; he argues that to do so would be to 'reduce politics to exceptional and vanishing moments of uprising' pointing out that 'the mere enactment of the political principle rarely-if ever-appears in its purity' (Rancière, as cited in Bowman \& Stamp, 2011, p. 5). Dissensus can therefore take place in the everyday practices of people who are resisting marginalisation, in locations that are not expected, nor traditionally conceptualised as holding radical potential. These occasions of democratic politics can be connected to Lefebvre's theory of 'moments'. Highmore (2002, p. 115) describes these moments as 'instances of intense experiences in everyday life that provide an immanent critique of the everyday [to] provide a promise of the possibility of a different daily life [that] puncture the present'. Through an intervention that symbolically and materially deconstructs everyday life, there is an increased awareness of new possibilities. This awareness opens the democratic imagination to the landscape of a better world in the distance.
The creation of alternative practices must begin with a rupture from the existing world, even if this occurs only in a temporary manner.

A rejection of the present opens possibilities for a different form of everyday life, which sets the foundation for the second element of everyday radicalism: collective rebellion. Through an analysis of migrant participation in city life, Hall (2015) introduces the concept of 'everyday resistance', in which the social becomes integral to political struggle. For Holloway (2012, p. 4), the actors involved in the struggle against injustice extend far beyond social movement activists to include 'ordinary rebels'. What holds most promise for Holloway (2012) is the refusal by these rebels to participate in everyday capitalist relations and the ways in which this refusal is brought together with the creation of an alternative way of 'doing'.

Holloway's (2012) idea of ordinary rebels opens the range of potential locations for social transformation. There is a value in locating the possibilities for social change in marginalised communities. Harding (1991, p. 130) notes that the everyday struggles of women (and other marginalised groups) are a valuable source of knowledge for 'strategies of political resistance to oppression and domination'. Harding contends that history has shown that these forms of daily resistance against injustice have often been more important than formal political institutions in securing better conditions and delivering social change. When everyday resistance is assembled as part of collective action through people cooperating to create something different, this becomes transformed into a collective rebellion. As Camus (2013, p. 28) argued, 'from the moment that a rebellion begins, suffering is seen as a collective experience, as the experience of everyone'. Individual resistance therefore becomes social rebellion.

A final component of everyday radicalism is still required to elevate collective rebellion into a clearer basis for social and political transformation. The notion of prefigurative politics can inform how this might happen. Prefigurative politics are based on 'social experiments' that critique the status quo and implement radically democratic practices to offer alternatives (Cornish, Haaken, Moskovitz, \& Jackson, 2016). Yates (2015) introduces the idea of prefigurative politics as a contestation of power in everyday life. Yates (2015, pp. 13-14) identifies five dynamics of pre-figuration: experimentation in alternative approaches to social life; developing new codes of collective conduct for interactions between participants; an intervention that temporarily or symbolically changes the material environment; the diffusion of ideas that go beyond the immediate group; and through the development of new ideological 'perspectives' based on imagining, learning and playing with different positions.

Connecting prefigurative politics with DIY social action holds transformative potential. Srnicek and Williams $(2016$, p. 502) note that the range of community initiatives delivered by the Black Panthers should be con- 
sidered radical because they were responding to people's immediate needs of survival, but also that critically the initiatives were situated as part of a wider struggle to create new means of social reproduction against capitalism, racism and imperialism. What can appear as micro-actions that make a local difference can be reconceptualised through a lens of prefigurative politics to articulate a more socially just vision for the future.

Prefigurative politics contain a strong utopian dimension. Sliwinski (2016, p. 433) notes how contemporary scholarship brings forward the location of utopia, closer than its previous positioning as a faraway place (Cooper, 2014; Levitas, 2013; Srnicek \& Williams, 2016; Wright, 2010). Wright's (2010) work on 'real utopias' opens up the possibilities for social change emerging out of alternative practices and collective interventions that are already happening at a smaller scale. These practices attempt to create new sets of social relations and can be developed and scaled up (Wright, 2010). Cooper (2014) provides an idea to strengthen the connection between utopia, prefigurative politics and social change: that we can learn from sites of alternative social action (which she calls 'everyday utopias') and the new sets of values they bring into the present. Micro-actions that practice alternative social relations can therefore be seen to have both practical and imaginative purposes. Cooper (2014, p. 11) argues that utopian imaginations can invigorate radical politics through the 'capacity to put everyday concepts, such as property, care, markets, work and equality, into practice in counter-normative ways'. By reconceptualising the dominant frameworks that shape social relations, the existing political economy can be defamiliarised. This destabilisation and re-conceptualisation of social life can expand the 'democratic imagination'. By imagining and enacting alternative practices, the possibilities of constructing them in the future become more likely and well-thought out.

This section has developed a theoretical framework of everyday radicalism based on how DIY social action can provide a rupture with dominant practices to provide a critique of the status quo; how these practices can be seen to constitute a collective rebellion and the creation of an alternative; and the ways in which this 'other doing' can inform strategies for social justice. The next section will show how everyday radicalism can be related to the practices of everyday makers through a case study of a women's project in Manchester, UK.

\section{Mums' Mart: A Case Study to Illuminate Everyday Radicalism}

To illustrate the potential relation of everyday radicalism to the practices of 'everyday makers', findings from a research project with a women's group in Wythenshawe, Manchester, are drawn upon. Wythenshawe was developed from the 1920s as the largest municipal estate in Europe to house people being moved from the slums in the centre of the city. It was designed by city plan- ners as a utopia. The local Cooperative Women's Guild (as cited in Boughton, 2016) described Wythenshawe as being part of:

the world of the future-a world where men and women workers shall be decently housed and served, where the health and safety of little children are of paramount importance, and where work and leisure may be enjoyed to the full.

The research was conducted at the United Estates of Wythenshawe (UEW). The UEW is a community group in Benchill, a local area in Wythenshawe, which is within the top one percent most 'deprived' areas in the UK. The identification of this 'deprivation' is based on the government Index of Multiple Deprivation which draws together statistics on local employment, income, health, education, housing, child poverty, and availability of local services. The top-down utopian dreams of the planners were clearly not realised.

UEW was established after a small group of everyday makers, led by local resident Greg Davies, converted a disused church into a community centre with a gym. The UEW supports a range of different activities. The most recent one of these is Mum's Mart, which was started by a group of women aged 18 to 72 . The women came together with support from UEW to deal with their shared concerns of isolation, anxiety, and the limitations of living with a low-income. The women now meet every week to have a meal while their children play together. They organise monthly 'market days' to sell handmade products, things that they have bought at a lower price in bulk, as well as food and drinks. Through the markets the women raise money to take their families away somewhere for a short while, which they otherwise would not be able to afford. Members of the Mums' Mart have also taken part in an international exchange with the South African alliance of Shack/Slum Dwellers International.

The case study research was based on creating a short evaluative film over six months (https:// vimeo.com/213951251). The study worked through an abductive approach to research, which is specifically geared towards the construction of theory, and is a less well-known approach to social science research. Abductive analysis involves a recursive process of double-fitting data and theories and focuses on finding new insights from the data to then inform the creation of new theories (Tavory \& Timmermans, 2014, p. 179). Different lines of enquiry evolved throughout the research process as a result of iterative interactions between the theories that were developed at the start (based on radical democracy and everyday makers) and the emerging empirical data. New insights were sparked through this correspondence to inform the ideas behind everyday radicalism that are presented in this article.

Using film can capture the embodied aspects of everyday life that are often neglected from textual accounts. Becker (1974) notes how visual sociologists will 
often avoid just waiting for 'something interesting' to happen. This increases the possibilities of including aspects of everyday life that might not necessarily have been in the researcher's original thoughts. As several of the women did not want to be filmed directly talking to the camera, the initial design for the documentary had to be adapted. Following this, cameras were given to participants for a trip that they made to Scotland. 13 disposable cameras were given out with simple instructions to try and photograph what Mums' Mart did.

The visual data produced through the research opened a new line of inquiry about the creation of spaces of rupture. This new insight on rupture was opened up as the photographs provided a clear contrast between mundane everyday life and the more memorable moments that stand out from the pictures. This flash of insight has been of critical importance in developing the concept of everyday radicalism. Interviews were done with 13 members of Mums' Mart. The aims of these interviews were to discuss reflections on the challenges that the participants experience daily and then explore the ways in which Mums' Mart was providing support to be able to address some of these.

The sections below will relate the practices of the Mums' Mart to the theories of everyday radicalism.

\section{Moments of Dissensus: Breaking from Everyday Marginality}

Everyday radicalism begins with a rupture from dominant social relations. This rejection of the present enables an immanent critique of the political economy. The case study explored how Mums' Mart was breaking from established everyday practices and discourses that are shaped by marginality. This marginality produces inequalities that are experienced through everyday life. The manifestations of these inequalities were identified by participants as a lack of access to spaces of social support, anxiety and insecurity, a lack of resources to participate in social life, and stigmatisation due to the participants' positions as working class mothers.

The following quote is from an interview with a Mums' Mart participant, a lone parent working in the care industry, talking about when she and Greg (the organiser of UEW), decided to set up the Mums' Mart:

the reason Mums' Mart got set up in the first place was because I had a conversation with Greg, in the school playground, because l'd come out of school crying about some anxiety issues my son had. And it led us to a conversation about our kids and, I can't afford to take my kids out. He was saying that's what the kids need, a day trip out. And he said...there's a few mum's that I've spoken to who are, you know, a bit down and, they're in similar situations. Shall we all get together and have a meal? I got that support when I needed it. So, it's important to me to help other people, who need it.
This 'moment' could be seen to represent a break from the everyday life of the participant, who had spoken about working part-time in the care industry with lowpay and regular occurrences of financial insecurity. She had also shared the impacts of domestic abuse that she had experienced. The participant's rejection of struggling alone with the injustices of her everyday life can be analysed as both a critique of the present and the opening up of the possibilities for alternative spaces and social relations.

The story told by the participant conjures up a moment of rupture when she had reached the end of her tolerance and become unable, or unwilling, to put up with her social situation any longer. This moment marks both a rejection of the present and her everyday realities of not being able to take her children out anywhere, as well as the need to do something about it. Put simply, the participant was fed up and decided with someone else to try and make a change (within the limitations of her power that are set by the social and political context of her life).

This moment reflects what Holloway (2012, p. 19) might describe as a "no...backed by an 'other doing'" in which the 'no...is not a closure, but an opening to a different activity, the threshold of a counter-world with a different logic and a different language'. The idea of a threshold reflects the original point of rejection and the basis of departure that is intended by the idea of rupture.

One of the Mums' Mart participants, a mother of three children, noted the mundane challenges of everyday life she experienced:

It's the repetitiveness of getting up, getting the kids ready, getting them to school, sort the house out, washing, ironing, going to work, coming home, getting the kids tea ready, bath, bed. It's constant. Every day it doesn't change. And that makes it mundane...there's nothing. There's nothing new. You know what I mean. Everything is the same, day in, day out, whatever you do. And there's nothing else to do. There's nowhere else to go. It can be challenging. When you've got young kids as well, and there's nothing to do with them. Then, what can you do? Everywhere else you go it's just too expensive. If you've got more than one child, you can't afford to do it. There's nothing in this area for people to do, so you need more money for transport, to get to where you want to be.

The mother's quote above shows some of the difficulties she experiences in her everyday life. Many of the participants from Mums' Mart spoke about being excluded from being able to do activities with their children; of the isolation of being the main carer; and about mental health problems that they experienced. These problems can reveal social injustice when viewed through a critical sociological reading of everyday life that problematises what might initially appear as mundane. The moment that Mums' Mart was established can be seen through the analytical prism of radical democracy as a 
collective rejection against structures of inequality and patriarchy, although the participants did not expressly formulate it in such terms. The moment of Mums' Mart becoming established represents a practice of everyday politics, marked through a rejection of the 'mundane' every day that is shaped by structural forces of inequality and discrimination. This refusal opens the possibilities for an alternative experience of everyday life.

\section{The Creation of Spaces of Collective Rebellion Against the Politics of Poverty}

Everyday radicalism includes a dimension of the ways in which the practice of everyday makers can create an alternative way of 'doing'. Relating Mums' Mart to the concept of everyday radicalism, these practices can be seen as the beginning of a microscopic alternative against the politics of poverty in the UK. The dominant politics of poverty individualises blame for poverty and ignores the structural inequalities that are produced and reproduced through the political economy. As the impacts of structural injustices and inequality are largely neglected in public policy discourses, the problems of poverty become re-packaged and reframed as a problem of the deficits within people who are marginal to the political economy. Mothers living in poverty are a target for stigmatising discourses. Jensen (2012) argues that a key element of this 'culturalisation of poverty' can be seen around notions of 'poor parenting'. Jensen argues that through this pathologising narrative, poverty is constructed as the product of 'poor' conduct and behaviour, rather than the result of deeply entrenched systemic inequalities.

In contrast to the dominant politics of poverty, Mums' Mart provides a non-judgmental site of everyday support. The creation of a non-judgemental space through Mums' Mart came up in all the interviews, and was described by a participant of Mums' Mart who cared for her son with disabilities:

That's the most important thing ever. Because even though people say they don't care what people think about them, they do. We're all worried that we're not doing the right thing. We're all worried that we're not parenting right you know, we're all worried that, you know people looking down on us...but nobody knows each other's circumstances, whereas here...everyone's got a different story. No one judges that person or that person, whereas outside of Mums' Mart, you don't tell everybody the ins and outs of your business.

The participants spoke about how being together creates networks of care that were previously absent in their lives. All the participants of Mums' Mart identified the value of shared experiences as the basis for generating solidarity and the creation of a non-judgmental space. Framed through everyday radicalism, Mums' Mart can be seen as a collective site of resistance to stigma. Jensen and Tyler (2015, p. 485) identify the need for a critical challenge to the "hegemony of a hardening anti-welfare common sense' and argue that the experiences of people who are most directly affected should be paid particular attention. Learning from the DIY social action of Mums' Mart can provide both a critique of the present and a contribution to knowledge about an alternative practice that establishes (on a micro-level) a different set of social relations.

That Mums' Mart have created this space themselves is significant. Tyler $(2013$, p. 12) identifies the limitations of options that exist for many people living in marginalised communities; she argues that the possibilities for marginalised people to change their lives through mobility, work or even escape from the system are not generally open. Tyler characterises this through a sense of 'capture' in which people are trapped as perceived 'failed' or 'non' citizens. This entrapment drives people to rebellion and it is through this act that political agency is exercised. Everyday collective rebellion can be interpreted a deliberate act by everyday makers to change their world. The attempt to create an alternative everyday can collectively generate power and agency within marginalised communities. On a practical level, the participants from Mums' Mart create opportunities to be able to take their children away together by raising money through the market that they cooperatively established and run every month. The impact of collectively developing agency is explained by the participant who had the original conversations that led to Mums' Mart being established:

With my own situation being through mental and emotional abuse, you know you're left feeling kind of worthless and rubbish. And doing the markets, it gave me purpose; it made me feel like I was doing something important. Helping other people and earning money for ourselves...that's important to me. I don't expect things to be given to me on a plate; I want to work hard for them.

Mums' Mart illustrates DIY social action that brings immediate improvements to the everyday lives of marginalised women and their families, while representing a practice of collective rebellion against material and symbolic injustices. Through the production of alternative social relations, the possibilities of conceptualising new futures are opened up, both for the women and beyond. Building on these practices as a basis to re-conceptualise dominant frameworks of political economy can potentially position Mums' Mart as a prefigurative space for marginalised women, which is created by marginalised women.

\section{Mutual Education and Becoming Pre-Figurative}

While Mums' Mart has not deliberately formulated their practices in prefigurative ways, it might be considered 
that they are creating an alternative to the dominant political frameworks of injustice and stigmatisation on a micro-scale. Reflecting back on Yates' five conditions of prefigurative politics and relating them to the findings from the case study, Mums' Mart can be seen to be prefigurative in four of the dynamics: Mums' Mart are experimenting with alternative approaches to social life by creating a space in which marginalised women can participate more meaningfully in society through being able to enjoy things that are considered to be a part of a minimum standard of living; they are developing new collective interactions and norms between participants through the creation of therapeutic networks of care among previously atomised and marginalised individuals; they are temporarily and symbolically changing their material environment, opening up spaces for a new 'everyday' through establishing a market where they are cooperatively in charge and going to places they would otherwise not be able to visit beyond their estate; and they have connected with organisations beyond their immediate group across the UK and with Shack/Slum Dwellers International.

The only dynamic that is missing from the conditions for prefigurative politics that Yates defined is that unlike defined 'prefigurative groups', Mums' Mart do not explicitly 'host, develop and critique political perspectives, ideas and social movement frames' (Yates, 2015, p. 14). For Yates it is the inclusion of 'perspectives' that distinguishes prefiguration as a political approach compared to counter-cultural projects that lack 'either a collective vision or preparedness to act in order to change wider society'. While the Mums' Mart participants have not explicitly or strategically developed a collective vision to change society, this does not mean that they do not have critical political perspectives that are collectively shared and practised. The re-conceptualisation of social life practised on a microscopic scale by the Mums' Mart can be seen in terms of distributed and generative relations of power based on cooperation, a feminist ethic of care, solidarity and considerations of social equality. Mums' Mart represents the beginning of a shared set of practices that reflect a collective vision, which can be developed as a basis of prefiguring a more just future.

There is potential to open up sites of mutual education between everyday makers and radical scholars to explore and connect ideas, knowledges and experiences. Radical pedagogical approaches articulated by Freire (1970) based on participatory approaches to support investigation, education and action can be applied with everyday radicalism. An adaptable concept of everyday radicalism can provide a basis for generative dialogue with everyday makers that can bring together theories of radical democracy with experiential knowledge and narratives of making tangible impacts on society. Through meaningful engagement, the practices of everyday makers can potentially become prefigurative and generate knowledge to inform the democratic imagination, while theories of radical democracy can be iter- atively developed. This dialogic encounter between theory and practice is the next stage in the conceptual development of everyday radicalism.

\section{Conclusion}

Mums' Mart has been described in this article as a collective practice by women who face similar challenges as a result of marginality. The women have begun to form therapeutic networks of care to reduce isolation and support each other. Their collective practices reflect the development of everyday social solidarities, which form the basis of Mums Marts' more cooperative approach. These cooperative relationships stand in distinction to the competitive and individualised social relations inherent the dominant mode of political economy. Mums' Mart provides an illustration of how everyday makers can provide an alternative to the status quo on a micro scale.

This article has argued that the DIY social action of 'everyday makers' can be related to theories of radical democracy to contribute knowledge for the development of social and political alternatives beyond the immediate context in which they are operating. A framework for everyday radicalism has been introduced to inform and shape this knowledge production. Everyday radicalism begins with an understanding of the elements of rupture that break away from conventional practices of everyday life, and the ways in which this serves as a critique of the present and an opening into alternative worlds. The second component of everyday radicalism is collective rebellion, explained as social activity that constitutes a deliberate act to change the immediate world in tangible ways and generate new forms of agency and power. Finally, the critique and development of an alternative has been connected to ideas of prefigurative politics to provide a basis for generating further dialogue that can inform the democratic imagination.

\section{Acknowledgments}

The author would like to thank all the participants from the case study. He would also like to thank his PhD supervisors, Liz Richardson and Kingsley Purdam, as well as the helpful comments of the reviewers. This work was supported by the Economic and Social Research Council [grant number 1504165].

\section{Conflict of Interests}

The author declares no conflict of interests.

\section{References}

Bang, H. (2005). Among everyday makers and expert citizens. In J. Newman (Ed.), Remaking governance: Peoples, politics and the public sphere (pp. 159-179). Bristol: Policy Press. 
Bassel, L., \& Emejulu, A. (2017). Minority women and austerity. Survival and resistance in France and Britain. Bristol: Policy Press.

Becker, H. (1974). Photography and sociology. Studies in the Anthropology of Visual Communication, 1(1), 3-26.

Blyth, M. (2013). Austerity: The history of a dangerous idea. Oxford: Oxford University Press.

Bookchin, M., Bookchin, D., \& Taylor, B. (2015). The next revolution. London: Verso.

Boughton, J. (2016, May 6). The Wythenshawe Estate, Manchester. Municipal Dreams. Retrieved from https://municipaldreams.wordpress.com/2013/04/ $02 /$ the-wythenshawe-estate-manchester-the-worldof-the-future

Bowman, P., \& Stamp, R. (2011). Reading Rancière. London: Continuum.

Bruff, I. (2014). The rise of authoritarian neoliberalism. Rethinking Marxism, 26(1), 113-129.

Camus, A. (2013). The rebel. London: Penguin Books.

Cooper, D. (2014). Everyday utopias. Durham, NC: Duke University Press.

Cornish, F., Haaken, J., Moskovitz, L., \& Jackson, S. (2016). Rethinking prefigurative politics: Introduction to the special thematic section. Journal of Social and Political Psychology, 4(1), 114-127.

Durose, C., \& Richardson, L. (2015). Designing public policy for co-production: Theory, practice and change. Bristol: Policy Press.

Freire, P. (1970). Pedagogy of the oppressed. New York, NY: The Seabury Press

Gardiner, M. (2010). Everyday utopianism: Lefebvre and his critics. Cultural Studies, 18(2/3), 228-254.

Gaventa, J. (2006). Finding the spaces for change: A power analysis. IDS Bulletin, 37(6), 23-33.

Hall, S. (2015). Migrant urbanisms: Ordinary cities and everyday resistance. Sociology, 49(5), 853-869.

Harding, S. (1991). Whose science? Whose knowledge? Ithaca, NY: Cornell University Press.
Highmore, B. (2002). Everyday life and cultural theory. London: Routledge.

Holloway, J. (2012). Crack capitalism. London: Sage.

Jensen, T. (2012). Tough love in tough times. Studies in the Maternal, 4(2), 1-26.

Jensen, T., \& Tyler, I. (2015). 'Benefits broods': The cultural and political crafting of anti-welfare commonsense. Critical Social Policy, 35(4), 470-491.

Levitas, R. (2013). Utopia as method. Basingstoke: Palgrave Macmillan.

Little, A., \& Lloyd, M. (2009). The politics of radical democracy. Edinburgh: Edinburgh University Press.

May, T. (2011). The political thought of Jacques Rancière. Edinburgh: Edinburgh University Press.

Morin, E. (1999). Homeland earth. London: Hampton Press.

Richardson, L. (2008). DIY community action. Bristol: Policy Press.

Sitrin, M., \& Azzellini, D. (2014). They can't represent us! Reinventing democracy from Greece to Occupy. London: Verso.

Sliwinski, A. (2016). The value of promising spaces: Hope and everyday utopia in a Salvadoran town. History and Anthropology, 27(4), 430-446.

Srnicek, N., \& Williams, A. (2016). Inventing the future. London: Verso.

Streeck, W. (2016). How will capitalism end? London: Verso.

Tavory, I., \& Timmermans, S. (2014). Abductive analysis. Chicago, IL: The University of Chicago Press.

Tyler, I. (2013). Revolting subjects: Social abjection and resistance in neoliberal Britain. London: Zed Books.

Walby, S. (2015). Crisis. Cambridge: Polity Press.

Wright, E. (2010). Envisioning real utopias. London: Verso.

Yates, L. (2015). Rethinking prefiguration: Alternatives, micropolitics and goals in social Movements. Social Movement Studies, 14(1), 1-21.

\section{About the Author}

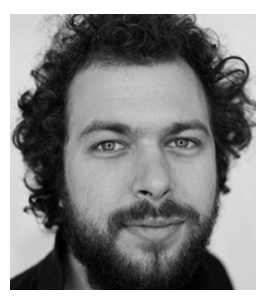

Dan Silver is a PhD candidate in the Department of Politics at the University of Manchester. His PhD research project is developing a more democratic approach to evaluation. Dan's research focuses on radical democracy, evaluation and public policy. 